\title{
Do Self-Regulation Skills of Preschoolers Mediate the Relation Between Parenting Behaviors and Peer Play Skills?
}

\author{
Dilan Bayındır ${ }^{1}$ \\ ${ }^{1}$ Necatibey Education Faculty, Balıkesir University, Balıkesir, Turkey \\ Correspondence: Dilan Bayındır, Necatibey Education Faculty, Balıkesir University, Balıkesir, Turkey.
}

Received: November 23, 2018

Accepted: December 30, $2018 \quad$ Online Published: March 20, 2019

doi:10.5539/ies.v12n4p74

URL: https://doi.org/10.5539/ies.v12n4p74

\begin{abstract}
The aim of this research is to examine the relations between parenting behaviors of mothers, self-regulation skills and peer play skills of preschool children between 60-72 months old focusing in particular the mediation role of the self-regulation skills in relation between parenting behaviors and peer play skills. The sample of the research is selected from the central districts of a city in middle western Turkey, by random sampling method. Sample of the study consist of 365 children, their mothers and teachers. The results indicate that there is a positive relation between positive parenting and positive play skills and a similar association between negative models. Although the self-regulation skills are positively associated with positive peer play, no significant relation is found between self-regulation and negative peer play behaviors. Additionally, no indirect effect of parenting behaviors on peer play skills through self-regulation skills was observed. Implications of the findings are discussed in the light of the related literature.
\end{abstract}

Keywords: preschool period, parenting behaviors, self-regulation skills, peer play skills

\section{Introduction}

\subsection{Self-Regulation}

Self-regulation is a multidimensional concept involving the regulation and control of emotion, behavior, attention and motivation (Kopp, 1982). Many different theoretical approaches such as the behaviorist, social cognitive, information processing and social-cultural approaches try to define the concept of self-regulation. The work done in this area is based on concepts such as "metacognition" which takes roots from information processing theory of Flavell (1979) and Brown (1987 cited in Yürük, 2014) and "self-regulation" which is mentioned in the socio-cultural theory of Vygotsky (1978) and socio-cognitive theory of Bandura (1986). Schunk (2001) defines self-regulation as the whole of planned and systematic emotions, thoughts and behaviors that the individual exhibits to achieve a certain purpose, by taking advantage of the cognitive, metacognitive and motivational strategies.

Self-regulation skills are related to social and moral competence (Kochanska, Murray, \& Harlan, 2000; Kochanska, Murray, Jacques, Koenig, \& Vandegeest, 1996), peer relationships (Ramani, Brownell, \& Campbell, 2010), emotional regulation (Carlson \& Wang, 2007, Simonds, Kieras, Rueda, \& Rothbart, 2007), psychological well-being (Eisenberg et al., 2004), school achievement (Blair, 2002; Blair \& Diamond, 2008; Ponitz, McChelland, Jewkes, Connor, Farris, \& Morrsion, 2008), mathematics and arithmetic success (Blair \& Razza, 2007; Bull \& Scerif, 2001), reading comprehension (Çetinkaya \& Erktin, 2002) and the effective classroom behavior (Ponitz et al., 2008).

\subsection{Self-Regulation Skills and Play Skills}

Play provides an effective development space for self-regulation skills seen in early childhood (Berk, Mann, \& Ogan, 2006; Ivrendi, 2016; Savina, 2014). Whitebread (2010) summarized the results of his research, concluding that play is supportive for high-level metacognition and self-regulation task performance. The necessity to comply with the rules that are inherent in each play has a crucial role in the development of self-regulation skills, one of the basic skills necessary for children to succeed in the structured classroom environment. Adherence to the rules also contributes to the development of self-control because it requires control of reactive behavior and indication of expected behavior. Vygotsky (1978) argues that children are more self-controlled during play than everyday activities. As a result, he argues that play constitute a proximal zone of development for children's self-control 
development (Savina, 2014).

During preschool years symbolic play dominates the other forms of play (Piaget, 1962; Vygotsky, 1978). There are studies that find a relationship between children's self-control skills and standard symbolic play (Ivrendi, 2016; Kelly \& Hammond, 2011). Similarly, Galyer and Evans (2001) point out that playing more symbolic play makes children more competent at emotional regulation. Bredekamp (2004) argues that self-regulatory skills will develop while children wait for his/her turn, learn to cooperate and regulate others's behaviors during play. When the children play, they will also check if their friends are following the rules. Regulating the behavior of others also has an important place in the development of self-regulation (Whitebread et al., 2009). Whitebread (2007) notes that support for play in educational settings influences children's learning, particularly self-directed learning behaviors.

A recent study by Ogan and Berke (2009), investigated the effects of symbolic plays promoted by adults and symbolic plays directed by adults on children's self-regulation skills (Meyers \& Berk, 2014). 45 children aged between 4-5 years were participated in the study. 24 children were guided during the play and given specific tasks. During the play, children were made directions to teach self-regulation skills such as planning, self-control, and follow-up rules. The researchers did not intervene in the play of children who are in the control group. Two weeks later, pre-test, post-test and follow-up test were performed to measure children's self-regulation skills. According to the results of the research, more symbolic play has been realized in the group where researchers support children. This study highlights the importance of adult support in play sessions to develop self-regulation skills of children.

\subsection{Parenting Behaviors and Play Skills}

The effects of parental behaviors and child development have become the subject of many researches. Existing literature indicate that warm, supportive parenting behaviors have strong influences on the positive development of children. Positive parenting attitudes positively affect child's cognitive development (Landry, Smith, Swank, Assel, \&Vellet, 2001; Meins et al., 2002), language development (Hutterlocker, Haight, Bryk, Seltzer, \& Lyons, 1991; Whitehurst et al., 1998), and social-emotional development (Eisenbergh et al., 2005; Landry et al., 2001). The effect of lack of explanation and punitive parenting behaviors on the development of the child is adverse (Ruffman, Perner, \& Parkin, 1999). Parenting behaviors also affect children's play behavior (Öğretir, 1999). It can be assumed that the effect of parenting behaviors on children's playful skills is shaped by the role of various mediating variables. For example, there are studies that relate the play skills with cognitive skills (Bergen, 2002), social skills (Mathieson \& Banerjee, 2011), language skills (Suhonen, Nislin, Alijoki, \& Sajaniemi, 2015). Parenting behaviors are one of the important factors affecting the development of cognitive, social and language skills. So, it is possible to mention the direct and indirect effects of parenting on play skills.

\subsection{Self-Regulation Skills and Parenting Behaviors}

One of the most important predictors of self-regulation skills are parenting behaviors (Kochanska et al., 2000; Olson, Bates, Sandy, \& Schilling, 2002). Kopp (1982) points out that early care is the key to the development of children's self-regulation skills. Social cultural and social cognitive theories argue that skills such as self-monitoring and attention are gained through social interactions and become part of the individual's cognitive and behavioral skills by internalization over time. This process evolves from 'other/non-regulated' to 'self-regulation' (Bodrova \& Leong, 2010; Schunk \& Zimmerman, 1997). With parental guidance, children learn what elements in the world need to be aware of. This support or "regulation by others" can lead to a transition from other-regulation to self-regulation in independent tasks (Rogoff, Mistry, Goncu, \& Mosier, 1993 cited in Harris, Robinson, Chang, \& Burns, 2007).

Bernier, Carlson, and Whipple (2010) assessed maternal sensitivity, mindedness, and autonomy support of parents with children between 12 and 15 months. And the influence of these three parenting dimensions on children's executive functions was investigated when children are at 18 and 26 months. They found that autonomy support was the most powerful predictor of children's executive function skills. When parents display insensitive and punitive behaviors, the self-regulation skills of children are also negatively affected (Eisenberg et al., 2010). For example, negative parental control can inhibit the development of attention and cognitive processes (Grusec \& Goodnow, 1994).

\subsection{The Present Study}

As it was mentioned above, parenting behaviors have strong influences on children's development (Eisenbergh et al., 2005; Landry et al., 2001; Meins et al., 2002; Whitehurst et al., 1998), as well as they affect play skills (Öğretir, 1999). The literature indicates that parenting behaviors are important predictors for the self-regulation skills in early childhood (Kochanska, et al., 2000; Olson, Bates, Sandy, \& Schilling, 2002) and play experiences provide 
opportunities for the development of these skills (Berk, Mann \& Ogan, 2006; İvrendi, 2016; Savina, 2014; Sezgin \& Demiriz, 2017; Tominey \& McClelland, 2011; Whitebread, 2007). Play activities simultaneously require and help to promote self-regulation (Nicolopoulou et al., 2015), so it could be said that high self-regulation skills support quality of play behavior.

The purpose of this study is to test the success of the theoretical model developed in explaining whether there is a causal relationship between self-regulation, parenting behaviors and peer play skill levels in preschool children. It is expected that this study will contribute to the related literature by examining a proposed model. The recommended model was depicted in Figure 1 below.

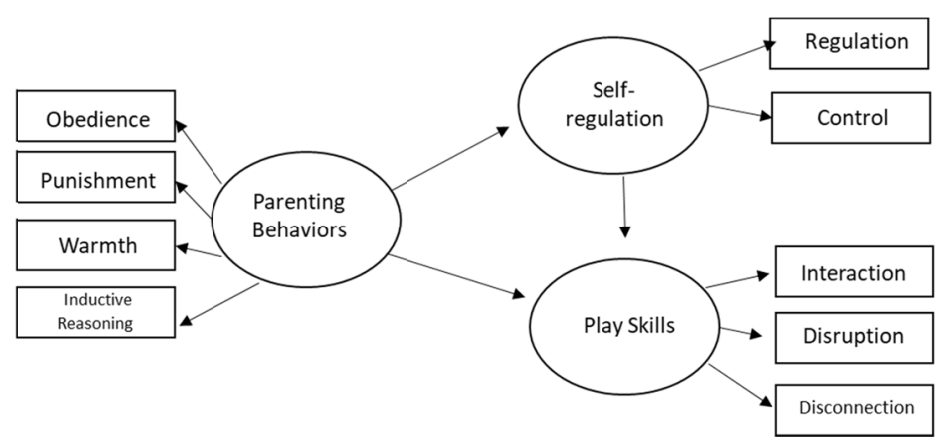

Figure 1. The recommended model

\section{Method}

\subsection{Design of the Study}

To test the developed model in examining whether there is a causal relationship between parenting behaviors, preschooler's self-regulation and play skills, structural equation model was used. It is a systematic tool is used to evaluate relations between variables in social sciences and testing theoretical models (Y1lmaz, 2004). Two basic models that were named as measure model and structure model. It is advised to start a good the structural equation model with measure model (Tezcan, 2008).

\subsection{The Sample of the Study}

The sample of the research is selected from the central districts of Balıkesir, Turkey by random sampling method. Sample of the study consist of 365 children. 167 (45.8\%) of children are female, whereas $198(54.2 \%)$ of them are male. The children are between 60-72 months old and the mean of their age is 65.79 months (Std. 4.46). 356 mothers participated in the study. The age distribution of the mothers is as follows: $2.5 \%$ are 25 years old and below, $23.2 \%$ are $26-30$ years old, $40.2 \%$ are $31-35$ years old, $24.3 \%$ are $36-40$ years old and $9.6 \%$ are 41 and above (1 missing). The distribution of their educational levels is as follows: $12.6 \%$ are primary school, $12.0 \%$ are secondary school, $39.9 \%$ are high school graduates, $30.9 \%$ have bachelor degrees and 3.0\% have master degrees $(6$ missing). The economic status of the family was determined by perceptions of the mothers. $1.6 \%$ of them stated their families' economic status as high, $83.3 \%$ stated as middle, 13.4\% stated as low (6 missing). 24 preschool teachers participated in the study by evaluating self-regulation skills of the participant children. All of them are female and work in state preschools.

\subsection{Data Collection Tools}

Self-Regulation Skills Scale (SRSS): The scale that was developed by Bayındır and Ural (2016) in Turkish consisting of 33 items assesses self-regulation skill levels of preschool children aged between 48-72 months. In each item, the teacher assesses the child's self-regulation skill level based on the likert type score of 5. The scale is composed of 2 subscales named as regulation (21 items) and control skills (12 items). "S/he sets goals for her/himself (for example, s/he tells or indicates s/he will build a tower in her/his length before he starts building the tower)" is an example of regulation subscale items. One item example from the control subscale skills scale is "S/he could shift her/his attention when passing from one activity to another". The Cronbach's Alpha value of the total scale was found to be .96 . The Cronbach Alfa values of each subscales scale were found as .96 for regulation and .91 for control skills. The test-retest value was calculated as .99 .

Parenting Questionnaire (PQ): The Parenting Questionnaire was developed by Sanson (1995 cited in Paterson \& Sanson, 1999). The 30-item questionnaire is used to measure parenting behaviors. In each item, the parent 
evaluates the frequency of their parenting behavior based on the likert type score of 5. It was adapted to Turkish by Yağmurlu and Sanson (2009). The Turkish form of the questionnaire consists of 30 items as in the original. There are totally 4 subscales of the scale. These are obedience, punishment, warmth and inductive reasoning. There are some examples of items under these four subscales; Obedience (e.g., "I expect my child to do what he/she is told to do, without stopping to argue about it."), Punishment (e.g., "I use physical punishment, e.g., smacking, for very bad behavior."), Warmth (e.g., "My child and I have warm, intimate times together."), Inductive Reasoning (e.g., "I try to explain to my child why certain things are necessary."). The Cronbach Alfa values of each subscales of the Turkish form were found as . 76 for inductive reasoning, .84 for punishment, .78 for obedience and .68 for warmth for the Turkish sample (Yağmurlu \& Sanson, 2009). This scale was delivered to the mothers with the help of the teachers.

Penn Interactive Peer Play Scale (Parent Form): The scale that is designed to help parents and teachers understand the peer play behaviors in early childhood settings, was developed by Fantuzzo, Mendez, and Tighe (1998) and later adapted into Turkish by Ahmetoğlu, Acar ve Aral (2016). It is a scale with 32 items and 3 subscales named as play interaction play disruption and play disconnection. Internal consistency values are $\alpha=.72$ for play interaction, $\alpha=.73$ for play disruption, $\alpha=.68$ for play disconnection.

\subsection{Data Collection}

The data was collected during spring semester of 2017-2018 academic year. The Self-Regulation Skills Scale was completed by the teachers of 60-72 months old children who attended preschool education institutions in Balıkesir Province in Turkey. The Parenting Questionnaire and Penn Interactive Peer Play Scale were filled in by the mothers of preschool children included in the sample group. While the scales were distributed to mothers by preschool teachers, a written text containing the purpose of the research and the contact information of the researcher were sent to the participant mothers. In the text, it was stated that data collection procedure do not include any identity information question belonging to the mother or child and the mothers could participate in the research on the basis of volunteerism, the data would only be used for this research and the information would be kept confidential. The filled in scales were collected back within two weeks.

\subsection{Data Analysis}

Two steps were used in data analysis. Firstly measurement models, where latent factors were created, were used. Secondly, predefined latent factors were tested through structural equation modeling (SEM). Each variable in the current study was tested for multivariate normality before running SEM models. None of the variables were out of accepted range for skewness and kurtosis (+- 2 for skewness and +- 7 for kurtosis (Curran, West, \& Finch, 1996). Therefore, no transformation was applied (See Table 1). Mplus version 7.0 was used for mediation model analysis (Muthen \& Muthen, 2012). The indirect effects were tested bu using bootstrapping analysis (MacKinnon, Fairchild \&Fritz, 2007). Chi-Square Model Fit ( $\chi 2$ ), Root Mean Square Error of Approximation (RMSEA), Non-Normed Fit Index (NNFI), Comparative Fit Index (CFI), and Goodness of Fit Index (GFI) were used to assess fit of the model.

Table 1. Descriptive statistics for all variables

\begin{tabular}{lccccc}
\hline Variables & $\mathrm{M}$ & $\mathrm{SD}$ & Range & Skewness & Kurtosis \\
\hline 1. PQ-Obedience & 2.60 & .75 & 3.83 & .15 & -.61 \\
2. PQ-Punishment & 1.64 & .37 & 2.50 & 1.28 & 2.64 \\
3. PQ-Warmth & 4.76 & .27 & 1.44 & -1.40 & 1.84 \\
4. PQ-Inductive Reasoning & 4.16 & .36 & 2.14 & -1.03 & .80 \\
5. PIPPS-Interaction & 2.96 & .48 & 2.33 & -.16 & -.38 \\
6. PIPPS-Disruption & 1.42 & .28 & 1.33 & .70 & .05 \\
7. PIPPS-Disconnection & 1.68 & .28 & 1.70 & .67 & .68 \\
8. SRSS-Regulation & 4.10 & .68 & 3.67 & -1.06 & 1.49 \\
9. SRSS-Control & 3.68 & .88 & 3.83 & -.51 & -.28 \\
\hline
\end{tabular}

Note. PQ: Parenting Questionnaire; PIPPS: Penn Interactive Peer Play Scale; SRSS: Self-Regulation Skills Scale

\section{Results}

\subsection{Measurement Models}

Measurement model with latent variables was run to test whether latent variable model fit the data. In the all 
models, comparative fit index (CFI), root mean square error of approximation (RMSEA), and standardized root mean square residual (SRMR) as model fit criteria were used. The model fit results were CFI $>.90, \mathrm{RMSEA}<.08$, SRMR < .06 (Browne \& Cudeck, 1992; MacCallum, Browne, \& Sugawara, 1996).

Confirmatory Factor Analysis (CFA) (Muthen \& Muthen, 2012) was used to run measurement model. Measurement model with all possible indicators (e.g., all peer play variables loading on peer play factor) did not fit the data and some of the indicators did not significantly load on the predefined factors, $\chi^{2}(24)=159.979, p<.000$, $\mathrm{CFI}=.61, \mathrm{RMSEA}=.12, \mathrm{SRMR}=.08$. Considering this misfit model, parenting and peer play factors were run in two separate latent-factor measurement models as positive model (i.e., positive parenting; warmth and inductive reasoning as indicators and, positive peer play; Interaction as indicator) and negative models (i.e., negative parenting; obedience and punishment as indicators and, negative peer play; disruption and disconnection as indicators). It was kept self-regulation with two indicators as both indicators (i.e., regulation and control) loaded stigmatically to the factor each time.

For the positive measurement model, model fit data well $\chi^{2}(3)=0.718, p=0.87, \mathrm{CFI}=.1 .00, \mathrm{RMSEA}=.00 \mathrm{SRMR}$ $=.01$. And standardized loadings for parenting factor were .76 for warmth and .58 for inductive reasoning, and for self-regulation were .78 for regulation and .60 for control. Given acceptable fit indices and loadings, we used this positive model mediation analyses.

For the negative measurement model, model fit data $\chi^{2}(9)=32.266, p<.000, \mathrm{CFI}=.91, \mathrm{RMSEA}=.08 \mathrm{SRMR}=.05$. And standardized loadings for parenting factor were .43 for obedience and .86 for punishment, and for self-regulation were .78 for regulation and .60 for control. Given acceptable fit indices and loadings, I used this negative model mediation analyses.

\subsection{Mediation Analyses}

For mediation models, MPlus (Muthen \& Muthen, 2012) was used to predict the children's peer play from parenting style and self-regulation. The significance of indirect effects was tested by using the resampling procedures of bootstrapping with confidence intervals (CI) of 95\% (MacKinnon, Fairchild, \& Fritz, 2007). Bootstrapping is used to generate empirical estimates of population distribution (Preacher \& Hayes, 2004). In all the mediation models, it was started model building by controlling for child gender, age and parent SES (which is created by averaging standardized scores of mother and father education level, and income of parents) as covariates. If one or all of the covariates were not associated with the target variable, it was removed the covariate or covariates from model for parsimonious and better model fit.

The Mediating Effect of Self-Regulation on The Association Between Positive Parenting and Negative Peer Play: First, it was tested the mediating effect of self-regulation on the association between positive parenting and negative peer play. The mediation model fitted the data very well, $\chi^{2}(9)=29.763, p<.000, \mathrm{CFI}=.91$, RMSEA $=.08, \mathrm{SRMR}=.04$. The direct effect from positive parenting to self-regulation to a negative peer play was specified. The direct effect from positive parenting to self-regulation was not statistically significant $(\beta=-.06, p$ $=.39$ ); however, the direct effects from self-regulation and positive parenting to negative peer play was statistically significant $(\beta=-.24, p=.01, \beta=-.32, p=.001$, respectively. Self-regulation did not mediate the association between positive parenting and negative peer play $(\beta=0.01, p=.49)$. See Figure 2 for the depiction of the mediation model.

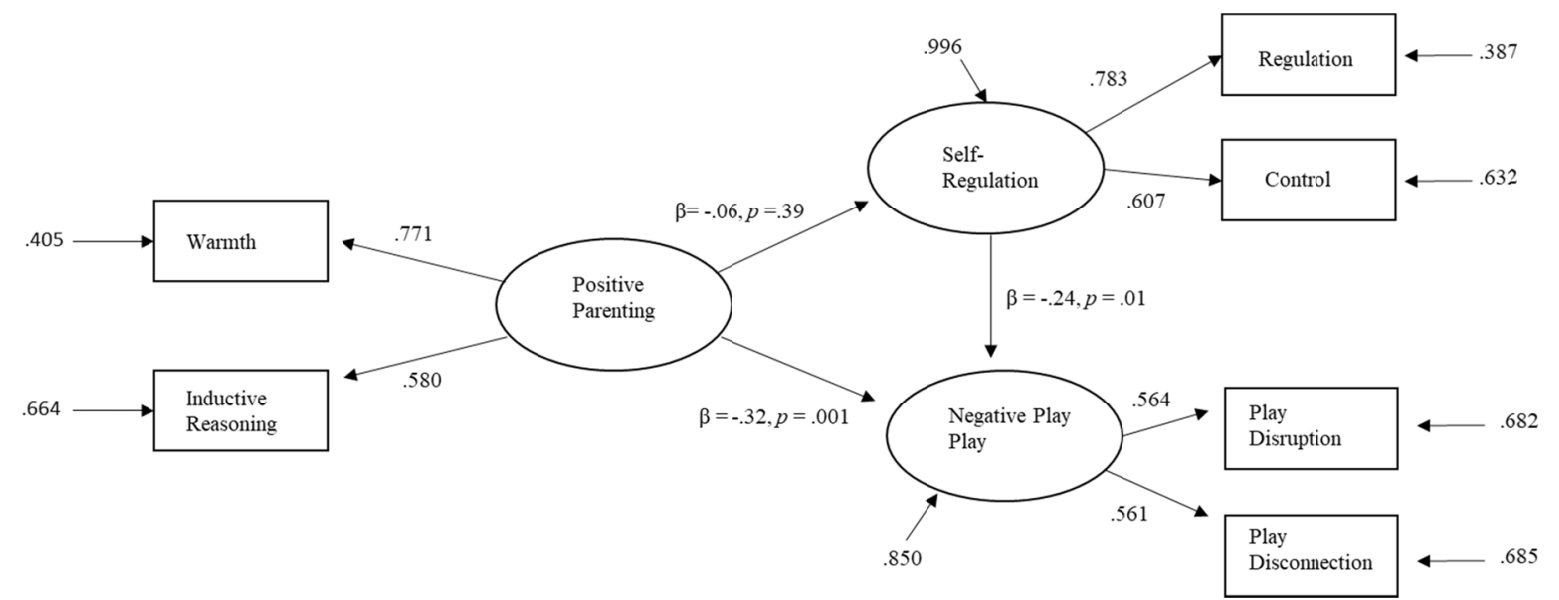

Figure 2. Mediation effect of self-regulation between positive parenting and negative peer play

(Indirect effect $=0.01, p=.49$ ) 
The Mediating Effect of Self-Regulation on The Association Between Positive Parenting and Positive Peer Play: Second, it was tested the mediating effect of self-regulation on the association between positive parenting and positive peer play. The mediation model fitted the data very well, $\chi^{2}(9)=29.199, p<.000, \mathrm{CFI}=.91$, RMSEA $=.07, \mathrm{SRMR}=.06$. The direct effect from positive parenting to self-regulation to positive peer play was specified. The direct effect from positive parenting to self-regulation was not statistically significant $(\beta=-.07, p=.39)$; however, the direct effects from self-regulation and positive parenting to positive peer play was statistically significant $(\beta=.18, p=.02, \beta=.33, p=.000$, respectively). Self-regulation did not mediate the association between positive parenting and positive peer play $(\beta=-0.01, p=.45)$. See Figure 3 for the depiction of the mediation model.

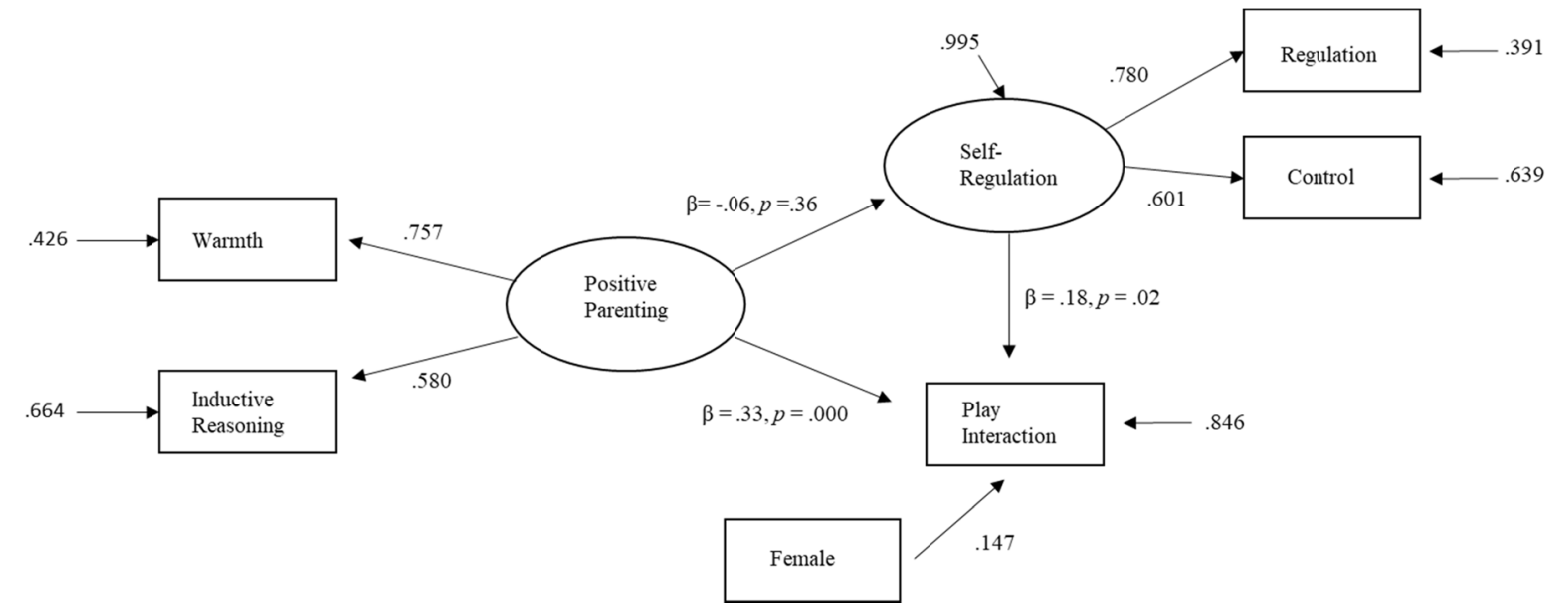

Figure 3. Mediation effect of self-regulation between positive parenting and positive peer play (Indirect effect $=-0.01, p=.36$ )

The Mediating Effect of Self-Regulation on The Association Between Negative Parenting and Positive Peer Play: Third, it was tested the mediating effect of self-regulation on the association between negative parenting and positive peer play. The mediation model had close fit the data, $\chi^{2}(9)=34.199, p<.000, \mathrm{CFI}=.86, \mathrm{RMSEA}=.08$, $\mathrm{SRMR}=.06$. The direct effect from negative parenting to self-regulation to a positive peer play was specified. The direct effect from negative parenting to self-regulation was not statistically significant $(\beta=-.16, p=.11)$; the direct effects from self-regulation to positive peer play was significant $(\beta=.14, p=.08)$ and negative parenting to positive peer play was not statistically significant $(\beta=-.14, p=.04)$. Self-regulation did not mediate the association between positive parenting and negative peer play $(\beta=-0.03, p=.27)$. See Figure 4 for the depiction of the mediation model.

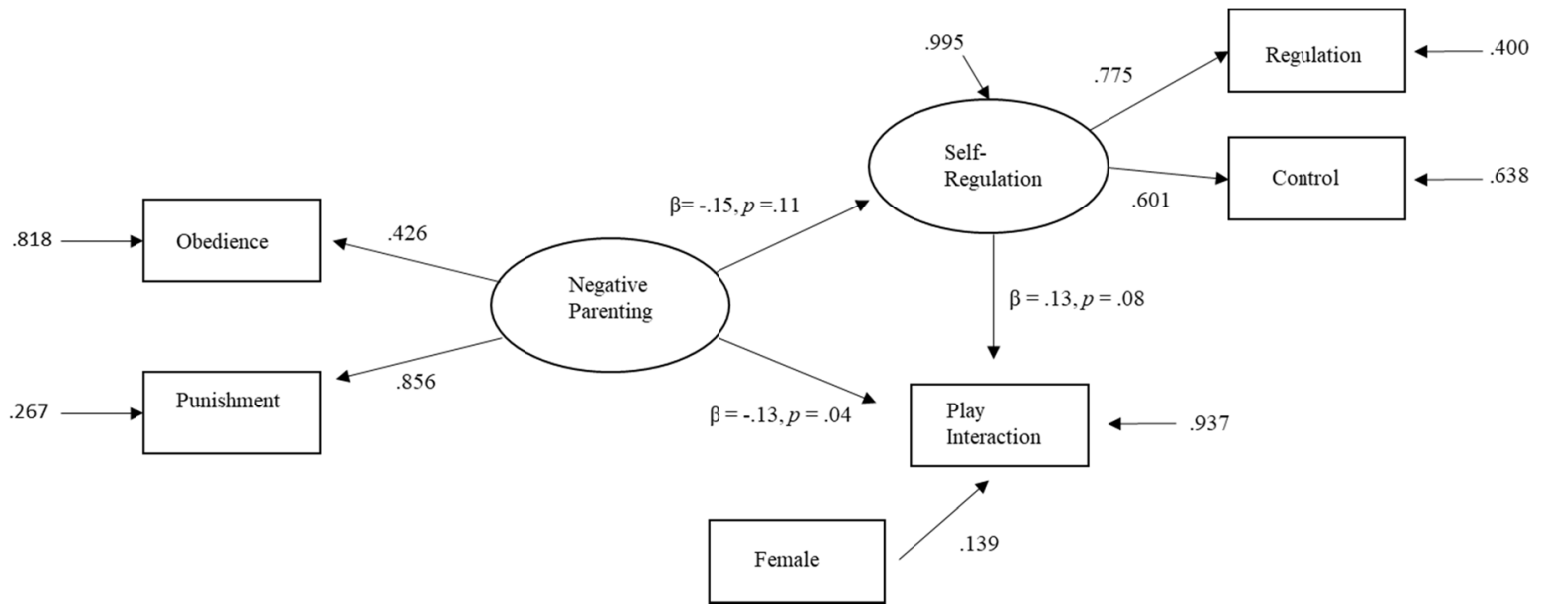

Figure 4. Mediation effect of self-regulation between negative parenting and positive peer play (Indirect effect $=0.03, p=.27$ ) 
The Mediating Effect of Self-Regulation on The Association Between Negative Parenting and Negative Peer Play. Fourth, it the mediating effect of self-regulation on the association between negative parenting and negative peer play was tested. The mediation model had a close fit to the data well, $\chi^{2}(9)=32.266, p<.000$, CFI $=.90$, RMSEA $=.08, \mathrm{SRMR}=.05$. The direct effect from negative parenting to self-regulation to a negative peer play was specified. The direct effect from negative parenting to self-regulation was not statistically significant $(\beta=-.16, p$ $=.07)$; the direct effects from self-regulation to negative peer play was not statistically significant $(\beta=-.13, p=.16)$ and negative parenting to negative peer play was statistically significant $(\beta=.55, p<.00)$. Self-regulation did not mediate the association between negative parenting and negative peer play $(\beta=0.02, p=.28)$. See Figure 5 for the depiction of the mediation model.

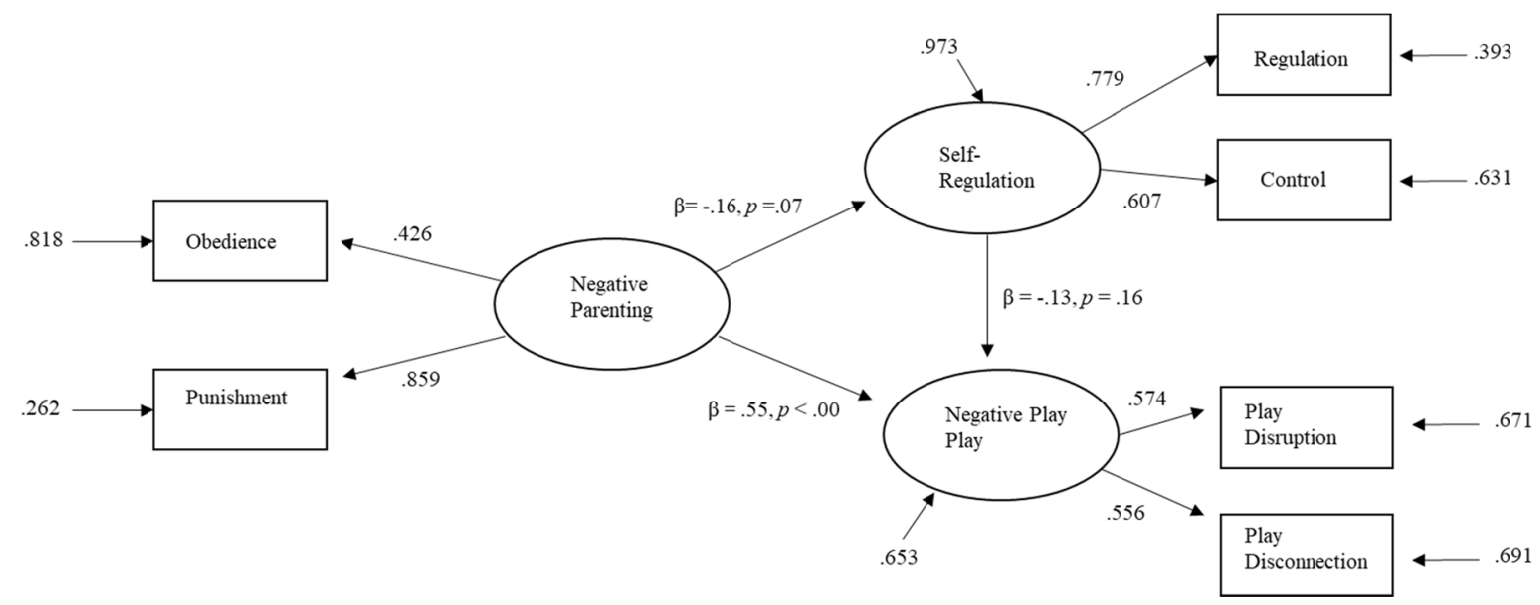

Figure 5. Mediation effect of self-regulation between negative parenting and negative peer play (Indirect effect $=0.03, p=.27$ )

\section{Discussion}

The aim of the study was to test the developed model's ability to examine if there are causal relationships between parenting behaviors, preschooler's self-regulation skills and peer play skills by considering the mediation role of self-regulation skills. Because the measurement model with all possible indicators did not fit the data and some of the indicators did not significantly load on the predefined factors, parenting and peer play factors were run in two separate latent-factor measurement models as positive and negative models. One of the most significant results of the study is that the mediation role of self-regulation skills between parenting behavior models and peer play models is not specified. The development pattern of self-regulation can lead to this finding. Vygotsky (1997) reports that the self-regulation develops as an interpersonal function when an adult regulates a child's behavior. Progressively, the child begins to regulate others' behavior. This kind of regulation can be seen especially during play. Then, an intrapersonal function occurs when the child masters true self-regulation. Also Vygotsky's (1978) claim stating that is children demonstrate greater self-control in play than in everyday life, could lead this finding. Some of the empirical study findings support this view. For example, Manuylenko (1948 cited in Savina, 2014) found that in the play condition, children were able to maintain the required pose for significantly longer time when an adult requests. Furthermore, the same finding might also be concluded since different variables can have effects on the relation between parenting behaviors and peer play skills. This finding is needed to be examined by longitudional and mixed model studies in order to determine the mediator role of self-regulation skills between the selected variables clearly. Also, various other measurement methods can be adopted to test the model.

Although it was found that self-regulation did not mediate the association between positive-negative parenting and positive-negative peer play models, the direct effects between variables are needed to be discussed. First of all, it could be stressed that the direct effects of parenting behaviors with peer play skills are significant. The results indicated that the relation between positive parenting skills and positive peer play skills is positively correlated. Also, positive parenting was found to be negatively related with the negative peer play skills. It is possible to consider the direct and indirect effects of the parenting behaviors on peer play skills. First of all, these findings are parallel to the ones that indicate relation between parenting and play skills (Lagacé-Séguin \& d'Entremont, 2006; Öğretir, 1999). Coaching parenting style raise the tools that will help children to regulate their behaviors and emotions (Gottman, Katz, \& Hooven, 1997). This helps children to regulate their behavior and emotions during 
play process. Lagacé-Séguin, and d'Entremont (2006) found that an emotion coaching parenting style was negatively related to the rough play. Also, it is well known that positive parental attitudes positively affect child's cognitive, language and social-emotional development (Eisenbergh et al., 2005; Hutterlocker, Haight, Bryk, Seltzer, \& Lyons, 1991; Landry et al., 2001, Meins et al., 2002., Whitehurst et al., 1998). Since the cognitive, language and social-emotional development skills are related with play skills (Bergen, 2002; Mathieson \& Banerjee, 2011, Suhonen, Nislin, Alijoki, \& Sajaniemi, 2015), it could be stated that parenting behaviors affect the play skills also in an indirect way.

The relation between parenting behaviors and self-regulation skills is not significant. It could be said that this finding is different than the related literature indicating that parenting behaviors is an important predictor of the self-regulation skills in early childhood (Bernier, Carlson, \& Whipple, 2010; Eisenberg et al., 2010; Grusec \& Goodnow, 1994; Kochanska et al., 2000; Kopp, 1982; Olson, Bates, Sandy \& Schilling, 2002). Also, the research done by using the same parenting behaviors and self -regulation skills scales in Turkey, indicated a positive relation between these variables (Bayındır, 2016). This finding may be the result of sample characteristics. The most significant difference of the samples of these two studies using the same scales is the location that the samples are selected from. Although the research that indicated relation between self-regulation skills of preschoolers and parenting skills was conducted in an urban area, the other one was implemented in a rural area. So, it is necessary to examine sample characteristics that may lead to differences on the relation between these variables.

Another result indicated that preschoolers with high levels of self-regulation skills had high levels of peer play skills. There is a reciprocal relationship between play skills and self-regulation skills. Play activities simultaneously require and help to promote both the cognitive abilities and capacities for social competence, such as self-regulation (Nicolopoulou et al., 2015). Pretend play and games with rules promote self-regulation skills (Swank, 2008). In this research, the type of play children engaged in was not controlled. However, it is known that during preschool years symbolic play dominates, while it is replaced with games with rules in the primary school period that covers the ages of 7-11 (Piaget, 1962; Vygotsky, 1978). So, it could be assumed that the participant children generally engaged in symbolic play. A study done by Elias and Berk (2002) indicated that engagement in sociodramatic play is beneficial on impulsive preschoolers in terms of self-regulation. The 'Tools of the Mind' curriculum that was developed by Bodrova and Leong (2007) which takes roots from the views of Vygotsky is one of the good examples of play-based curriculums. This curriculum supports play skills of preschoolers by teacher support in play planning, monitoring play process and coaching. The outcomes of application of the curriculum indicated significant outperformance on inhibitory control, working memory, and cognitive flexibility (Diamond, Barnett, Thomas, \& Munro, 2007). Bredekamp (2004) argues that self-regulatory skills will develop while children wait for his/her turn, learn to cooperate and regulate others' behaviors during play. When the children play the game, they will also check if their friends are following the rules. Regulating the behavior of others also has an important place in the development of self-regulation (Whitebread et al., 2009). Whitebread (2007) notes that support for play in educational settings influences children's learning, particularly self-directed learning behaviors. For this reason, it is suggested that educational environments should support children's play activities.

The findings also pointed out that the girls are evaluated as having more advanced peer play skills by their mothers. It is possible to state that this finding is parallel to the relevant literature that indicates the gender differences in play activities. Although boys' play involves more active and forceful physical contact, girls emphasize cooperation and use communication to promote group harmony (Maccoby, 1990). Also, this finding could be resulted from perceptions of adults because the peer play skills were evaluated by their parents. The literature indicates that girls are more likely to participate in adult structured activities and the activities that are governed by social rules (Smith \& Inder, 1993). So, this could lead to higher grades in favor of girls.

This study has several limitations. First of all, the parenting behaviors and peer play skills of preschoolers were evaluated by the participant mothers. In addition, the self-regulation skills of preschoolers were rated by the participant teachers. The data on these variables could be collected from multiple resources. Also, the data was collected at one time point. A longitudinal study design could be used to investigate the changes in the examined variables over time.

There are some suggestions that could be specified by examining the findings of the study. First of all, it is needed to design further studies to examine the mediator role of self-regulation skills between parenting behaviors and peer play skills by longitudinal and mixed model studies to determine this role clearly. Also, the findings pointed out the importance of positive parenting behaviors for development of self-regulation and positive peer play skills of preschoolers. So, supporting positive parenting behaviors by various educational, support and intervention programs could be one of the suggestions of the study. Furthermore, play based curriculums such as 'Tools of the Mind' could be applied to promote children in development of the self-regulation skills. Also, it can be suggested 
to include games with rules in preschool curriculum, since the games with rules are more structured and demands more self-regulation compared to symbolic play (Reid, 2001; Vygotsky, 1978). The games such as The Green-Light/Red-Light, Simon Says, Sculpture Game and Head-Toes-Knees-Shoulders could be used especially to support the inhibitory control skills of preschoolers.

\section{Acknowledgments}

This research was supported by the Scientific Research Projects Department of Balikesir University. Project no: 2017/149.

\section{References}

Ahmetoğlu, E., Acar, İ. H., \& Aral, N. (2016). Reliability and validity study of Penn Interactive Peer Play Scale-Parent form (PIPPS-P). Turkish Studies, 11(9), 31-52. https://doi.org/10.7827/TurkishStudies.9634

Bandura, A. (1986). Social foundations of thought and action: A social cognitive theory. Englewood Clifs, NJ: Prentice Hall.

Bayındır, D., \& Ural, O. (2016). Development of the Self-Regulation Skills Scale. International Online Journal of Educational Sciences, 8(4), 119-132. https://doi.org/10.15345/iojes.2016.04.011

Bayındır, D. (2016). Development of the self-regulation skills scale for 48-72 months old children and the investigation of the relationship between the level of self regulation skills of preschoolers and attachment security, maternal parenting behaviors and maternal psychological well-being (Unpublished doctorate thesis). Marmara University, İstanbul, Turkey.

Bergen, D. (2002). The role of pretend play in children's cognitive development. Early Childhood Research and Practice, 4(1), 1-13.

Berk, L. E., Mann, T. D., \& Ogan, A. T. (2006) Make-believe play: Wellspring for development of self regulation, In D. G. Singer, R. M. Golinkoff, \& K. Hirsh-Pasek (Eds.), Play Learning: How Play Motivates and Enhances Children's Cognitive and Social-Emotional Growth (pp. 74-100), Oxford: Oxford University Press. https://doi.org/10.1093/acprof:oso/9780195304381.003.0005

Bernier, A., Carlson, S. M., \& Whipple, N. (2010). From external regulation to self regulation: Early parenting precursors of young children's executive functions. Child Development, 81(1), 326-339. https://doi.org/10.1111/j.1467-8624.2009.01397.x

Blair, C., \& Diamond, A. (2008). Biological processes in prevention and intervention: The promotion of self-regulation as a means of preventing school failure. Development and Psychopathology, 20, 899-911. https://doi.org/10.1017/S0954579408000436

Blair, C., \& Razza, R. P. (2007). Relating effortful control, executive function, and false belief understanding to emerging math and literacy ability in kindergarten. Child Development, 78, 647-663. https://doi.org/10.1111/j.1467-8624.2007.01019.x

Blair, C. (2002). School readiness. American Psychologist, 57, 111-127. https://doi.org/10.1037/0003-066X.57.2.111

Bodrova, E., \& Leong, D. J. (2007). Tools of the mind: The Vygotskian approach to early education. Upper Saddle River, NJ: Pearson Education.

Bredekamp, S. (2004). Play and school readiness. In E. F. Zigler, D. G. Singer, \& S. J. Bishop-Josef (Eds.), Children's play: The roots of reading (pp. 159-174). Washington, DC: Zero to Three Press.

Bronfenbrenner, U. (1986). Ecology of the family as a context for human development: Research perspectives. Developmental Psychology, 22, 723-742. https://doi.org/10.1037/0012-1649.22.6.723

Browne, M. W., \& Cudeck, R. (1992). Alternative ways of assessing model fit. Sociological Methods and Research, 21, 230-258. https://doi.org/10.1177/0049124192021002005

Bull, R., \& Scerif, G. (2001). Executive functioning as a predictor of children's mathematics ability: Inhibition, switching, and working memory. Developmental Neuropsychology, 19, 273-293 https://doi.org/10.1207/S15326942DN1903_3

Carlson, S. M., \& Wang, T. S. (2007). Inhibitory control and emotion regulation in preschool children. Cognitive Development, 22, 489-510. https://doi.org/10.1016/j.cogdev.2007.08.002

Çetinkaya, P., \& Erktin, E. (2002). Assessment of metacognition and its relationship with reading comprehension, achievement and aptitude. Boğaziçi University Journal of Education, 19, 1-11. 
Charlesworth, W. R., \& Dzur, C. (1987). Gender comparisons of preschoolers' behavior and resource utilization in group problem solving. Child Development, 58, 191-200. https://doi.org/10.2307/1130301

Curran, P. J., West, S. G., \& Finch, J. F. (1996). The robustness of test statistics to nonnormality and specification error in confirmatory factor analysis. Psychological Methods, 1(1), 16-29. https://doi.org/10.1037/1082-989X.1.1.16

Diamond, A., Barnett, S., Thomas, J., \& Munro, S. (2007). Preschool program improves cognitive control. Science, 318, 1387-1388. https://doi.org/10.1126/science.115148

Eisenberg, N., Haugen, R., Spinrad, T. L., Hofer, C., Chassin, L. \& Zhou, Q. (2010). Relations of temperament to maladjustment and ego-resiliency in at-risk children. Social Development, 19, 577-600.

Eisenberg, N., Spinrad, T. L., Fabes, R. A., Reiser, M., Cumberland, A., Shepard, S. A., ... Thompson, M. (2004). The relations of effortful control and impulsivity to children's resiliency and adjustment. Child Development, 75, 25-46. https://doi.org/10.1111/j.1467-8624.2004.00652.x

Eisenberg, N., Zhou, Q., Spinrad, T. L., Valiente, C., Fabes, R. A. \& Liew, J. (2005). Relations among positive parenting, children's effortful control, and externalizing problems: A three-wave longitudinal study. Child Development, 76, 1055-1071. https://doi.org/10.1111/j.1467-8624.2005.00897.x

Elias, C. L., \& Berk, L. E. (2002). Self-regulation in young children: Is there a role for sociodramatic play? Early Childhood Research Quarterly, 17, 216-238. https://doi.org/10.1016/S0885-2006(02)00146-1

Fantuzzo, J., Mendez, J., \& Tighe, E. (1998). Parental assessment of peer play: Development and validation of the parent version of the Penn Interactive Peer Play Scale. Early Childhood Research Quarterly, 13, 659-676. https://doi.org/10.1016/S0885-2006(99)80066-0

Flavell, J. H. (1979). Metacognition and cognitive monitoring: a new area of cognitive developmental inquiry. The American Psychologist, 34, 906-911. https://doi.org/10.1037/0003-066X.34.10.906

Galyer, K., \& Evans, I. (2001). Pretend play and the development of emotion regulation in preschool children. Early Child Development and Care, 166, 93-108. https://doi.org/10.1080/0300443011660108

Gottman, J. M., Katz, L. F., \& Hooven, C. (1997). Meta-emotion: How families communicate emotionally. Mahwah, NJ, Lawrence Erlbaum Associates.

Grusec, J. E., \& Goodnow, J. J. (1994). Impact of parental discipline methods on the child's internalization of values: A reconceptualization of current points of view. Developmental Psychology, 30, 4-19. https://doi.org/10.1037/0012-1649.30.1.4

Harris, R. C., Robinson, J. B., Chang, F., \& Burns, B. M. (2007). Characterizing preschool children's attention regulation in parent-child interactions: The role of effortful control and motivation. Journal of Applied Developmental Psychology, 28, 25-39. https://doi.org/10.1016/j.appdev.2006.10.006

Huttenlocher, J., Haight, W., Bryk, A., Seltzer, M., \& Lyons, T. (1991). Early vocabulary growth: Relation to language input and gender. Developmental Psychology, 27, 236-248. https://doi.org/10.1037/0012-1649.27.2.236

İvrendi, A. (2016). Choice-driven peer play, self-regulation and number sense. European Early Childhood Education Research Journal, 24(6), 895-906. https://doi.org/10.1080/1350293X.2016.1239325

Kelly, R., \& Hammond, S. (2011). The relationship between symbolic play and executive function in young children. Australasian Journal of Early Childhood, 36(2), 21-27.

Kochanska, G., Murray, K. T., \& Harlan, E. T. (2000). Effortful control in early childhood: Continuity and change, antecedents, and implications for social development. Developmental Psychology, 36, 220-232. https://doi.org/10.1037/0012-1649.36.2.220

Kochanska, G., Murray, K. T., Jacques, T. Y., Koenig, A. L., \& Vandegeest, K. A. (1996). Inhibitory control in young children and its role in emerging internalization. Child Development, 67, 490-507. https://doi.org/10.1111/j.1467-8624.1996.tb01747.x

Kopp, C. (1982). Antecedents of self-regulation: A developmental perspective. Developmental Psychology, 18, 199-214. https://doi.org/10.1037/0012-1649.18.2.199

Lagacé-Séguin, D. G., \& d'Entremont, M. R. L. (2006). The role of child negative affect in the relations between parenting styles and play. Early Child Development and Care, 176(5), 461-477.

Landry, S. H., Smith, K. E., Swank, P. R., Assel, M. A., \& Vellet, S. (2001). Does early responsive parenting 
have a special importance for children's development or is consistency across early childhood necessary? Developmental Psychology, 37(3), 387-403. https://doi.org/10.1037/0012-1649.37.3.387

MacCallum, R. C., Browne, M. W., \& Sugawara, H. M. (1996). Power analysis and determination of sample size for covariance structure modeling. Psychological Methods, 1, 130-149. https://doi.org/10.1037//1082-989X.1.2.130

Maccoby, E. E. (1990). Gender as a social category. In S. Chess, \& M. E. Hertzig (Eds.), Annual progress in child psychiatry and child development (pp. 127-150). New York: Brunner/Mazel.

MacKinnon, D. P., Fairchild, A. J., \& Fritz, M. S. (2007). Mediation analysis. Annual Review of Psychology, 58, 593-614. https://doi.org/10.1146/annurey.psych.58.110405.085542

Mathieson, K., \& Banerjee, R. (2011). Peer play, emotion understanding, and socio-moral explanation: The role of gender. British Journal of Developmental Psychology, 29(2), 188-196. https://doi.org/10.1111/j.2044-835X.2010.02020.x

Meins, E., Fernyhough, C., Wainwright, R., Das Gupta, M., Fradley, E., \& Tuckey, M. (2002). Maternal mind-mindedness and attachment security as predictors of theory of mind understanding. Child Development, 73(6), 1715-1726. https://doi.org/10.1111/1467-8624.00501

Meyers, A. B., \& Berk, L. E. (2014). Make believe play and self regulation. London: Sage. https://doi.org/10.4135/9781473907850.n6

Muthen, L. K., \& Muthen, B. O. (2012). Mplus user's guide. Los Angeles, CA.

Nicolopoulou, A., Schnabel-Cortina, K., Ilgaz, H., Brockmeyer-Cates, C., \& de Sa, A. B. (2015). Using a narrative- and play-based activity to promote low-income preschoolers' oral language, emergent literacy, and social competence. Early Childhood Research Quarterly, 31, 147-162. https://doi.org/10.1016/j.ecresq.2015.01.006

Öğretir, A. D. (1999). Alt ve üst sosyo-ekonomik düzeydeki 6 yaş çocuklarının sosyal oyun davranışlarıyla anne-baba tutumlart arasindaki ilişkinin incelenmesi (A study on the relationship between six aged childrens social play behavior and parental attitudes from low and upper socio-economic levels) (Unpublished master thesis). Gazi University, Ankara, Turkey.

Olson, S. L., Bates, J. E., Sandy, J. M., \& Schilling, E. M. (2002). Early developmental precursors of impulsive and inattentive behavior: From infancy to middle childhood. Journal of Child Psychology and Psychiatry, 43, 435-447. https://doi.org/10.1111/1469-7610.00035

Paterson, G., \& Sanson, A. (1999). The association of behavioral adjustment to temperament, parenting and family characteristics among 5-year-old children. Social Development, 8(3), 293-309. https://doi.org/10.1111/1467-9507.00097

Piaget, J. (1962). Play, dreams, and imitation in childhood. New York, NY: Norton.

Ponitz, C. E. C., McClelland, M. M., Jewkes, A. M., Connor, C. M., Farris, C. L., \& Morrison, F. J. (2008). Touch your toes! Developing a direct measure of behavioral regulation in early childhood. Early Childhood Research Quarterly, 23, 141-158. https://doi.org/10.1016/j.ecresq.2007.01.004

Preacher, K. J., \& Hayes, A. F. (2004). SPSS and SAS procedures for estimating indirect effects in simple mediation models. Behavior Research Methods, Instruments, and Computers, 36, 717-731. https://doi.org/10.3758/BF03206553

Ramani, G. B., Brownell, C. A., \& Campbell, S. B. (2010). Positive and negative peer interaction in 3-and 4-year-olds in relation to regulation and dysregulation. The Journal of Genetic Psychology, 171(3), 218-250. https://doi.org/10.1080/00221320903300353

Reid, S. E. (2001). The psychology of play and games. In C. Schaefer, \& S. E. Reid (Eds.), Game play: Therapeutic use of childhood games (pp. 1-36). New York, NY: John Wiley \& Sons.

Ruffman, T., Perner, J., \& Parkin, L. (1999). How parenting style affects false belief understanding. Social Development, 8, 395-411. https://doi.org/10.1111/1467-9507.00103

Savina, E. (2014). Does play promote self-regulation in children? Early Child Development and Care, 184(11), 1692-1705. https://doi.org/10.1080/03004430.2013.875541

Schunk, D. H., \& Zimmerman, B. J. (1997). Social origins of self-regulatory competence. Educational Psychologist, 32, 195-208. https://doi.org/10.1207/s15326985ep3204_1 
Schunk, D. H. (2001). Social cognitive theory and self-regulated learning. In B. J. Zimmerman, \& D. H. Schunk (Eds.), Self-regulated learning and academic achievement: Theoretical perspectives (2nd ed., pp. 125-151). Manwah, NJ: Lawrence Erlbaum.

Sezgin, E., \& Demiriz, S. (2017). Effect of play-based educational programme on behavioral self-regulation skills of 48-60 month-old children, Early Child Development and Care, 1-14. https://doi.org/10.1080/03004430.2017.1369972

Simonds, J., Kieras, J. E., Rueda, M. R., \& Rothbart, M. K. (2007). Effortful control, executive attention, and emotional regulation in 7-10-year-old children. Cognitive Development, 22, 474-488. https://doi.org/10.1016/j.cogdev.2007.08.009

Smith, A. B., \& Inder, P. M. (1993). Social interaction in same and cross gender pre-school peer groups: A $\begin{array}{lllll}\text { participant observation study. Educational Psychology, } & \text { 13(1), }\end{array}$ https://doi.org/10.1080/0144341930130104

Suhonen, E., Nislin, M. A., Alijoki, A., \& Sajaniemi, N. K. (2015). Children's play behavior and social communication in integrated special day-care groups. European Journal of Special Needs Education, 1-17. https//doi.org/10.1080/08856257.2015.1009707

Swank, J. M. (2008). The use of games: A therapeutic tool with children and families. International Journal of Play Therapy, 17(2), 154-167. https://doi.org/10.1037/1555-6824.17.2.154

Tezcan, C. (2008). Yapısal eşitlik modelleri (Structural equation models) (Unpublished master thesis). Hacettepe University, Ankara, Turkey.

Tominey, S. L., \& McClelland, M. M. (2011). Red light, purple light: Findings from randomized trial using circle time games to improve behavioral self-regulation in preschool. Early Education \& Development, 22(3), 489-519. https://doi.org/10.1080/10409289.2011.574258

Vygotsky, L. S. (1978). The role of play in development. In M. Cole, V. John-Steiner, S. Scribner, \& E. Souberman (Eds.), Mind and society: The development of higher mental process (pp. 92-104). Cambridge, MA: Harvard University Press.

Vygotsky, L. S. (1997). The history of development of higher mental functions. In R. W. Rieber (Ed.), The collected works of L. S. Vygotsky (Vol. 4). New York, NY: Plenum Press.

Whitebread, D. (2007). Developing independence in learning. In J. Moyles (Ed.), Early Years Foundations: Meeting the Challenge (pp. 220-238). Maidenhead: Open University Press.

Whitebread, D. (2010). Play, Metacognition and Self-regulation. In P. Broadhead, J. Howard, \& E. Wood (Eds.), Play and Learning in the Early Years (pp.161-177). London: Sage.

Whitebread, D., Coltman, P., Pino-Pasternak, D., Sangster, C., Grau, V., Bingham, S., ... Demetriou, D. (2009). The development of two observational tools for assessing metacognition and self-regulated learning in young children. Metacognition and Learning, 4, 63-85. https://doi.org/10.1007/s11409-008-9033-1

Whitehurst, G. J., Falco, F. L., Lonigan, C. J., Fischel, J. E., Debaryshe, B. D., ValdezMenchaca, M. C., \& Caulfield, M. (1998). Accelerating language development through picture book reading. Developmental Psychology, 24, 552-559. https://doi.org/10.1037/0012-1649.24.4.552

Yağmurlu, B., \& Sanson, A. (2009). The role of child temperament, parenting and culture in the development of prosocial behaviors. Australian Journal of Psychology, 61(2), 77-88. https://doi.org/10.1080/00049530802001338

Yılmaz, V. (2004). Lisrel ile yapısal eşitlik modelleri: Tüketici şikâyetlerine uygulanması (Structural Equation Models with Lisrel: Application to Consumer Complaints). Anadolu University Journal of Social Sciences, 4(1), 77-90.

Yürük, N. (2014). Özdüzenlemede üstbiliş (Metacognition in self-regulation), In G. Sakız (Ed.), Özdüzenleme, Öğrenmeden öğretime özdüzenleme davranışlarının gelişimi, stratejiler ve öneriler (Self-regulation, development of self-regulation behaviors in learning, strategies and recommendations) (pp. 29-47). Ankara: Nobel.

\section{Notes}

Note 1. This study was presented at the 14th International Conference on Social Sciences, which was held between 2-3 March 2018 at Goethe University. 


\section{Copyrights}

Copyright for this article is retained by the author(s), with first publication rights granted to the journal.

This is an open-access article distributed under the terms and conditions of the Creative Commons Attribution license (http://creativecommons.org/licenses/by/4.0/). 